\title{
Montuhotep-Nebtawyre and Amenemhat I: Observations on the Early Twelfth Dynasty in Egypt
}

\author{
PETER JÁNOS I \\ Associate Professor, Institute of Egyptology, University of Vienna
}

S ince the Egyptian priest Manetho wrote his Aigyptiaca in the third century B.C., the chronology of ancient Egypt has been structured according to a system of so-called dynasties, sequences of rulers who were united by kinship or by regional origin or city of residence or both. While the interior sequence of rulers of most of the thirty dynasties is in many cases reasonably well attested, the transitions from one dynasty to the next are often difficult to understand and reconstruct. A good example of that kind of problem is the transition between Dynasties 11 and 12 at the beginning of the Middle Kingdom.

The end in about 1991 B.C. of Dynasty 11, ruling from Thebes, and the passing of power to the founder of Dynasty 12, King Amenemhat I (see Figure 1), who subsequently moved the capital again to a traditional location in the greater Memphite region, are obscured by the lack of sufficient contemporary evidence. Montuhotep-Nebtawyre (IV), ${ }^{1}$ generally regarded as the seventh and last ruler of the Theban Dynasty, ${ }^{2}$ is an enigmatic figure who-except for a number of rock inscriptions and one depiction ${ }^{3}$-left hardly any record. ${ }^{4}$ No monuments, buildings, or statues ${ }^{5}$ of this monarch are known, and his final resting place is still uncertain. ${ }^{6}$ Adding to this paucity of contemporary records, later sources, namely the pharaonic king lists and the surviving extracts of Manetho's Aigyptiaca, omit MontuhotepNebtawyre's reign. ${ }^{7}$ The entry in the thirteenth-century B.C. Turin Papyrus actually states that after the rule of six kings of the Eleventh Dynasty a period of seven unassigned or "empty" years (wsf rnpt 7) occurred, ${ }^{8}$ underscoring the obscurity of this transitional period. ${ }^{9}$ Given Nebtawyre's omission in later records and the "empty years" noted in the Turin Canon, an inscription carved in the Wadi Hammâmât

Metropolitan Museum Journal 45

(C) 2010 The Metropolitan Museum of Art, New York
(No. 191) naming Montuhotep-Nebtawyre's mother Imy as the king's mother but not a king's wife was considered evidence that she was not of royal blood and that her son was consequently a usurper. ${ }^{10}$ In actual fact Imy's titulary is not atypical for the period and does not permit any far-reaching conclusions as to the monarch's legitimacy, ${ }^{11}$ nor does the available evidence support any theories concerning a conflict between two opposing monarchs. ${ }^{12}$

In every discussion of Montuhotep-Nebtawyre and in any attempt to shed light on the historical events at the end of Dynasty 11, a tiny object forms a crucial piece of evidence. It is a fragment originating from a slate bowl (Figure 2) that was found by The Metropolitan Museum Egyptian Expedition at Lisht-North, site of the pyramid of Amenemhat I and the cemetery of his adjacent capital of It-Towy. ${ }^{13}$ The piece was originally part of a large stone vessel about $12 \frac{1}{4}$ inches $(31 \mathrm{~cm})$ in diameter inscribed on the inner and

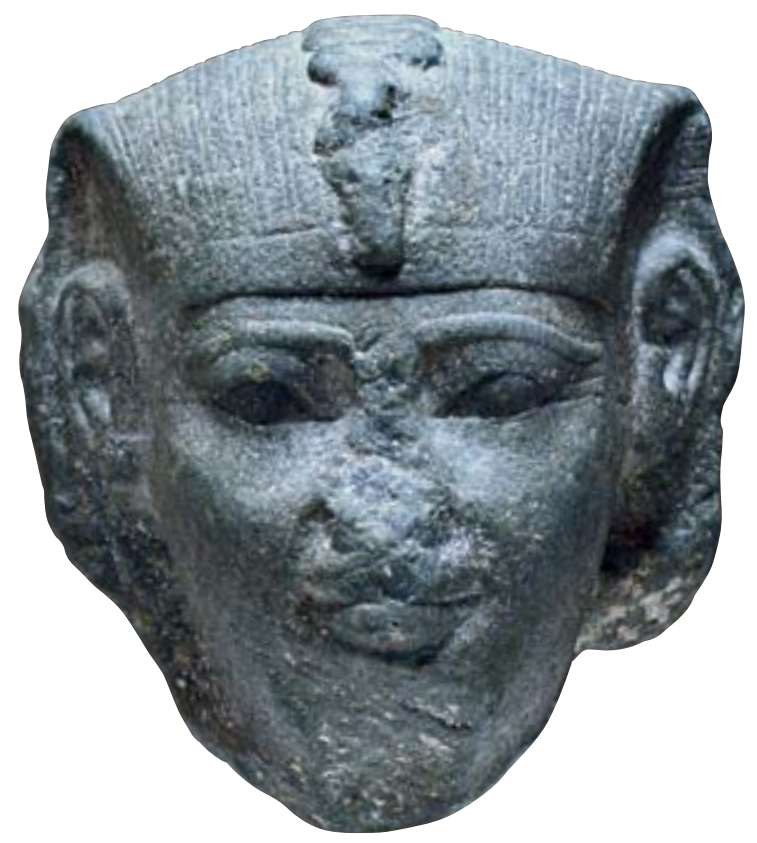

1. Head of a sphinx of Amenemhat I. Lebanon, possibly Tyre; Egyptian, Middle Kingdom, Dynasty 12, reign of Amenemhat I, ca. 19911962 B.C. Green dolomitic marble, H. $5 \frac{1}{2} 2$ in. $(14.1 \mathrm{~cm})$. The Metropolitan Museum of Art, Purchase, Fletcher Fund and The Guide Foundation, Inc. Gift, 1966 (66.99.4) 
2. Front and back of a fragment (enlarged here) of a bowl with the names of kings Montuhotep (Dynasty 11) and Amenemhat I (Dynasty 12). Found by The Metropolitan Museum Egyptian Expedition at Lisht-North. Egyptian, Middle Kingdom, 2051-1650 B.C. Slate, $15 / 8 \times 15 / 8$ in. (4 $\times 4 \mathrm{~cm})$. The Metropolitan Museum of Art, Rogers Fund, 1909 (09.180.543)

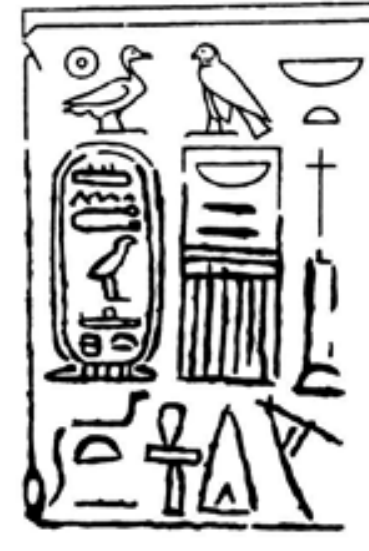

3. Reconstruction of the inscription on the outside of the bowl fragment in Figure 2 according to Herbert E. Winlock (1941, pl. 21)

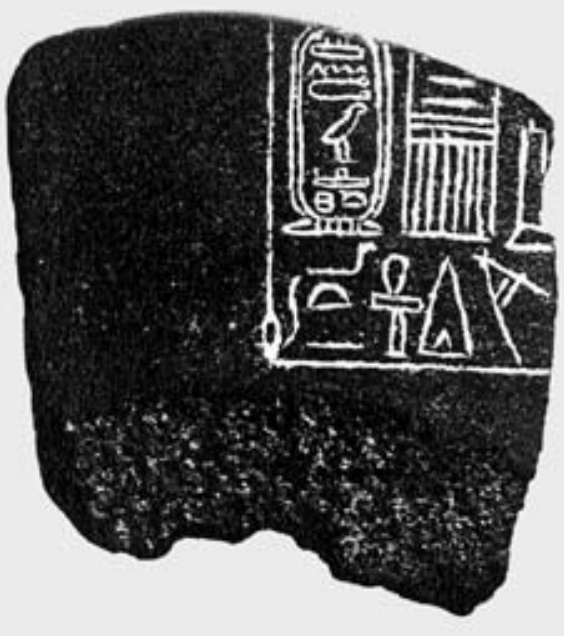

outer sides (see Figure 9). ${ }^{14}$ On the outside of the fragment appears the protocol of "Horus [ ] tawy, the son of Re, Montuhotep," and on the inside that of "Horus Wehemmesut" (Amenemhat I).

Despite its potential historical significance for the early Middle Kingdom, the importance of the tiny fragment was not recognized for many years. Although the slate fragment was discovered in 1907 or 1908, it was not published until 1941, in an article by Herbert E. Winlock with the somewhat misleading title "Neb-hepet-Re Mentu-Hotep of the Eleventh Dynasty." ${ }^{15}$ Winlock was concerned not so much with Montuhotep-Nebhepetre (now known to be Montuhotep II) as with the question of Montuhotep-Nebtawyre's position within the succession of the kings of the Eleventh Dynasty, a much-debated issue in those days. ${ }^{16}$ The incomplete inscription was restored by the archaeologist (Figure 3) as the name of the last ruler of Dynasty 11, [Horus Neb]tawy, Montuhotep (IV). Winlock reasoned further that an object like a slate bowl could hardly have survived the fifty-one year reign of Montuhotep-Nebhepetre or the twelve-year reign of his successor, Montuhotep-Seankhkare, and concluded that Horus Nebtawy must have ruled after these two monarchs; he argued that since Nebtawy's name was found with that of Amenemhat I on the same object, Nebtawy clearly must have been Amenemhat I's immediate predecessor. ${ }^{17}$ In Winlock's opinion the tiny fragment was unquestionably contemporary with Nebtawy's poorly documented reign. ${ }^{18}$ Concluding his historical reconstruction, he maintained that the monarch was one of the men who struggled for power during the seven-year period recorded in the Turin Canon. ${ }^{19}$

In his well-written book The Rise and Fall of the Middle Kingdom at Thebes, published in 1947, Winlock introduced another piece of evidence into the discussion on Montuhotep-Nebtawyre's reign. ${ }^{20}$ In 1915 the Department of Egyptian Art in The Metropolitan Museum of Art registered the lower part of a blue glazed tablet found at Lisht

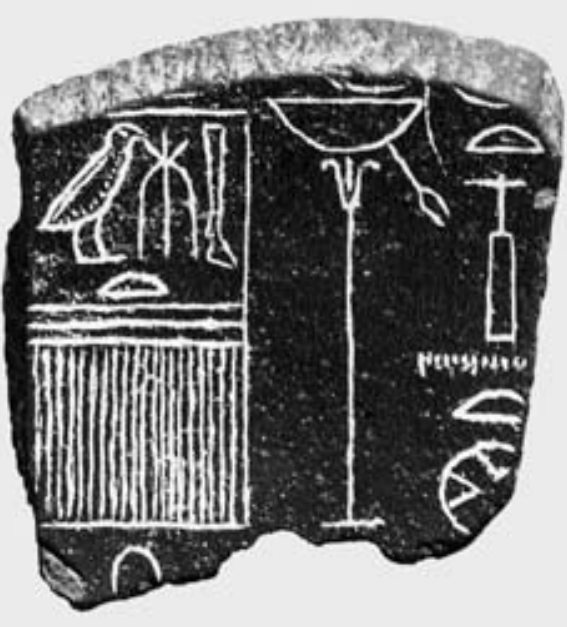

that bore the cartouche of a king "[ ]hotep" (Figure 4). William C. Hayes proposed reconstructing the incomplete name as [Montu] hotep and identifying it with the last ruler of Dynasty 11 (Figure 5, left). ${ }^{21}$ Adding the evidence of this fragment to that of the slate piece, Winlock decided that Horus Nebtawy "thought that he had actually started a new line of rulers over Egypt, which he hoped would rule the land from It-Towy." 22

Twenty-five years later, in a discussion of the historical conundrums of the early Middle Kingdom, in particular the change of the first two names of Amenemhat I's full protocol, Jürgen von Beckerath used the inscription on the slate fragment as evidence that Montuhotep-Nebtawyre was not in disgrace during Amenemhat I's reign, although the later records might seem to suggest otherwise. ${ }^{23}$ In von Beckerath's opinion, Amenemhat I showed his respect for his predecessor by adding his own name to the slate bowl. Carrying his theory a step further, von Beckerath speculated that the weak monarch Montuhotep-Nebtawyre had finally been forced to accept as coregent his powerful vizier Amenemhat, who eventually became sole ruler and founder of a new dynasty after Montuhotep-Nebtawyre's death. ${ }^{24}$

Until now the incomplete text on the slate bowl has been accepted as corroborating the existence of some sort of relationship between these two monarchs. ${ }^{25}$ Furthermore, it has seemed that if Amenemhat I added his name on an artifact of his predecessor, it must have been the case that he respected the last ruler of the preceding dynasty. ${ }^{26}$ When the inscribed slate fragment is reexamined, however, a number of details emerge that clarify some points in the discussion summarized above and make possible another, historically more convincing reconstruction of the incomplete text. First of all, it is useful to deal with the incomplete tablet that Winlock referenced as further evidence of Nebtawyre's existence at It-Towy (Figure 4). In fact it can be shown that this tiny object has no significance for the history of Nebtawyre's rule. It is not at all evident that the object 
should be associated with this monarch. The tablet was found in layers dating to later periods and not in a securely dated context of the early Twelfth Dynasty. ${ }^{27}$ Furthermore, the royal name in the cartouche is incompletely preserved, leaving only the lower part intact. A small trace of a sign was preserved in the upper left part of the cartouche, which Winlock reconstructed as the legs of the quail chick (the $w$-sign, Gardiner sign list G43) in order to restore the name as "Montuhotep." His reconstruction (see Figure 5, left), however, would position the $w$-sign far to the left in the cartouche and create an overly close and awkward arrangement with the $t$-sign (Gardiner sign list V13). Written in vertical cartouches the $w$ is usually positioned as a central element under the $\underline{t} \cdot{ }^{28}$ But even if the inscription on the tablet is correctly reconstructed as the name Montuhotep, it is of little significance, for without further evidence the name could be linked with any of the rulers of the Eleventh or even with two kings of the Thirteenth Dynasty (Montuhotep $\mathrm{V}$ and Montuhotep VI). ${ }^{29}$ Looking again at the small traces reconstructed as the tail and legs of the quail chick, it is apparent that they actually fit quite well into a restoration of the sign that depicts a shrine with the recumbent crocodile on top (Gardiner sign list 14), the horizontal trace fitting into the lower left edge of the shrine and the vertical trace preserving the end of the animal's tail (Figure 5, right). The name could thus be restored as either Sobekhotep, used by a number of kings during Dynasty 13, or as Sobekhotepre, the name of King Sobekhotep I. ${ }^{30}$ In the final analysis, therefore, this incomplete object has no significance for Montuhotep IV's rule.

As to the slate bowl itself, it must be stressed at the outset that even in the current understanding of the inscriptions, the bowl fragment is unsuited to support von Beckerath's theory that Montuhotep-Nebtawyre and Amenemhat I might have been coregents. Winlock had already realized that the inscriptions differ in form and execution and that they were carved by two different artists. ${ }^{31}$ Furthermore, as William J. Murnane has rightly pointed out, Amenemhat I's Horus name is given as Whm-mswt, while von Beckerath's idea had been that the monarch used another Horus and Nebty name (Sehetepibtawi) during the coregency period. ${ }^{32}$ There is in fact absolutely no evidence that Amenemhat I added his name to the slate bowl at the very beginning of his reign. ${ }^{33}$ This misconception rests on the erroneous assumption that the appearance of both names on the same object indicates a historical link between the two monarchs. Absent the many rock inscriptions testifying that the Vizier Amenemhat (commonly believed to be the later King Amenemhat I) ${ }^{34}$ served under the last ruler of Dynasty 11, the slate bowl fragment alone would not be enough to prove even a close temporal relationship between these two individuals..$^{35}$ The slate fragment testifies only that a bowl made for a specific purpose at a specific place was inscribed by a monarch of the Eleventh Dynasty and later reused by the founder of the Twelfth Dynasty.

As Winlock has observed, the two inscriptions on the bowl fragment (Figure 2) were clearly executed by two different persons. In both cases the texts are incomplete, but the preserved parts display fine and careful carving. The older inscription on the outside shows smaller signs and a somewhat clumsy arrangement of the hieroglyphs in the horizontal line at the bottom. The Amenemhat I inscription features larger hieroglyphs with some inner details (see the feathers[?] of the $w$-bird in the Horus name). Differences can also be observed in the rendering of individual hieroglyphs. While the iwn-pillar (Gardiner sign list O28) on the outside is shown with a pedestal, the same sign has none in the Amenemhat I
4. Lower part of a tablet with the incomplete royal name of a king "[ ]hotep." Found by The Metropolitan Museum Egyptian Expedition at Lisht-North. Egyptian, Middle Kingdom, 20511650 B.C. Faience, $17 / 8 \times 13 / 4$ in. $(4.7 \times 4.3 \mathrm{~cm})$. The Metropolitan Museum of Art, Rogers Fund, 1915 (15.3.916)

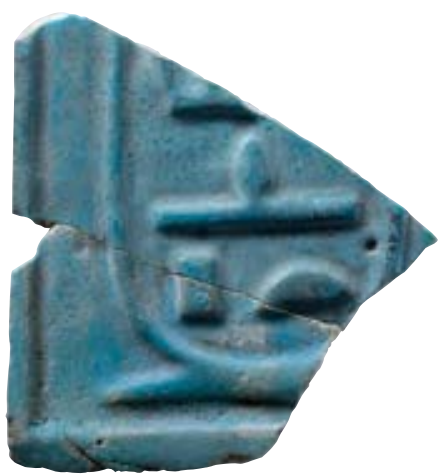

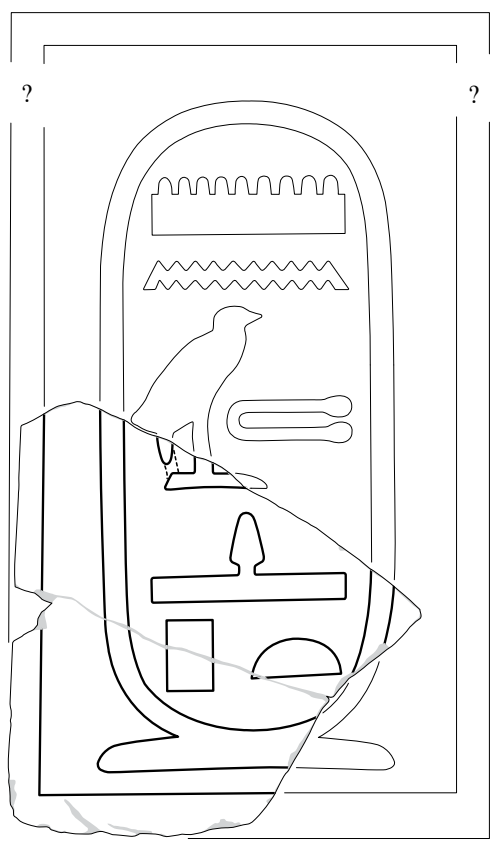

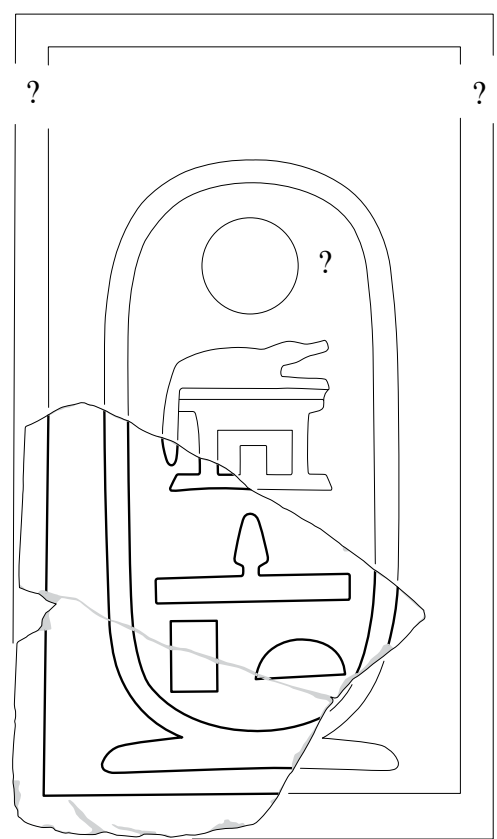

5. Left: reconstruction of the royal name on the incomplete faience tablet in Figure 4 according to Hayes (1953, p. 176) and Winlock (1947, p. 54). Right: reconstruction of the royal name with the Sobek shrine as the central element. Drawing: Liza Majerus 
6. Bowl. From Tomb M12, Abydos, Egypt. Early Dynastic Period, ca. 3100-2900 B.C. Slate; H. $3 \frac{1 / 4}{4}$ in. $(8.1 \mathrm{~cm})$, Diam. $57 / 8$ in. $(15 \mathrm{~cm})$. The Metropolitan Museum of Art, Gift of Egypt Exploration Fund, 1902 (02.4.57)
7. The royal panel from a temple relief at Armant, showing the name of MontuhotepSeankhkare (left) with the emblem of Upper Egypt, the goddess Nekhbet of Elkab. The serekh-panel comprising the king's Horus name is taller than the cartouche of his throne name. Drawing: Mond 1940, pl. 94

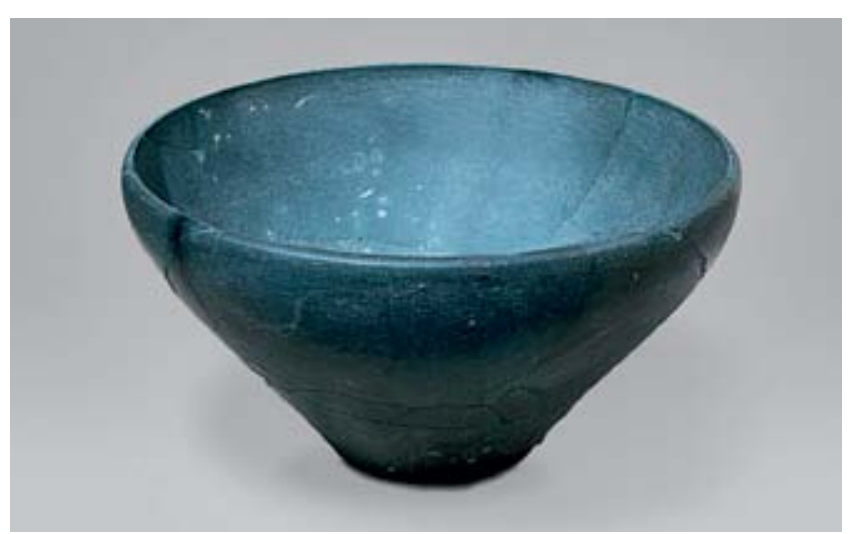

inscription. The $n$ sign (Gardiner sign list N35) on the outside in Montuhotep's cartouche is rendered as a short waterline of conventional form, while the same sign on the interior, where it occurs facing the serekh of Amenemhat I in the name of Dendera (Iunit), is executed with short and irregular vertical strokes set next to each other.

Although incomplete, both inscriptions furnish valuable information concerning the object's use in antiquity. In both texts the royal names face the text "beloved of Hathor, mistress of Dendera." ${ }^{\prime 36}$ While the Montuhotep text consists of the $s 3-R^{c}$ and Horus names of the royal protocol, Amenemhat l's Horus name faces the emblem of Uto (Wadjit), which is then followed by the Hathor text. It is remarkable that Hathor of Dendera is combined with the emblem of Uto, the Lower Egyptian crown goddess, to face the king. The arrangement suggests that to the left of Amenemhat l's Horus name the inscription probably continued with the monarch's $s 3-R^{c}$ name faced by the emblem of Nekhbet of Elkab (see Figure 7). The deity at the far left could have been a falcon-headed god, presumably Montu of Thebes, who was popular at that time. ${ }^{37}$

While the identification and restoration of the later inscription poses few problems, the older text as reconstructed by Winlock (Figure 3) merits further comment. First,
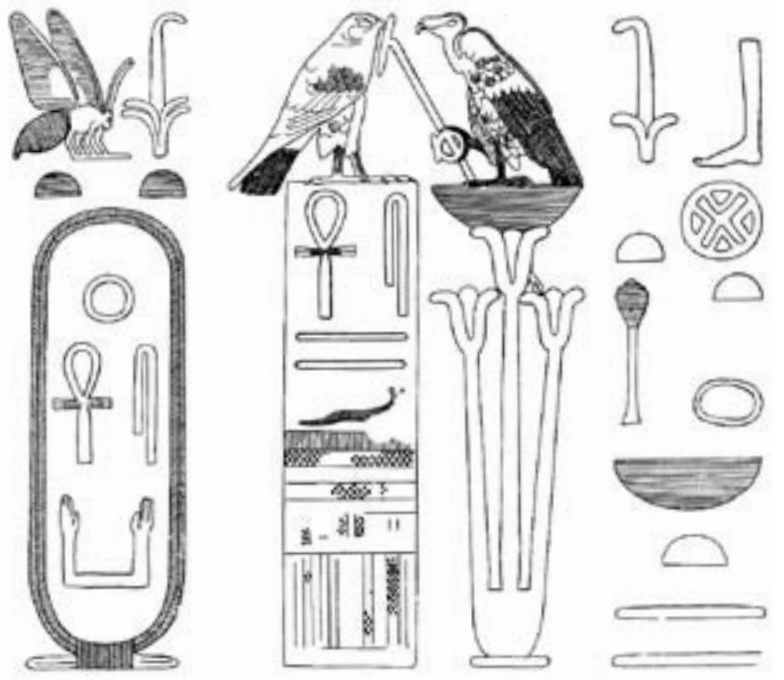

in Winlock's reconstruction the falcon on top of the Horus name facing the $s 3-R^{c}$ name should be reversed. In inscriptions containing a deity as part of the royal protocol the name (or names) of the king either faces the same direction as the deity (see the Mentuhotep-Nebhepetre tablets from Deir el-Bahari) ${ }^{38}$ or confronts him or her (see Figures 7, 11). ${ }^{39}$ Second, when Winlock published the fragment he was of the opinion that "an object of so little intrinsic value" could hardly have survived the long reigns of Montuhotep IV's predecessors-Montuhotep-Nebhepetre (fifty-one years) and Montuhotep-Seankhkare (twelve years) - so that the bowl must have been carved near the time of Amenemhat I's reign. ${ }^{40}$ At first glance the argument seems reasonable, but the same argument would then require the assumption that the bowl was reinscribed early in Amenemhat I's twentynine-year reign. Since the object carries the monarch's later titulary, however, the assumption of a very early date for the carving can be refuted. And opinions about the durability of the bowl are not of paramount importance in the reconstruction of the incomplete royal name.

As to the bowl itself, if it were the insignificant object Winlock considered it to be, one wonders why it was inscribed by at least two different monarchs. Both inscriptions clearly mention Hathor of Dendera, the most important female deity of the late Eleventh Dynasty, and probably a male deity as well, rendering it possible that the bowl originated from a sanctuary at Dendera. Because the object was part of a temple inventory, it cannot be excluded that other monarchs-perhaps even kings of the Old Kingdomhad left their names on the vessel. It is well known, for example, that Kings Teti and Pepi I (Dynasty 6, 2323-2150 B.C.) felt a special devotion to Hathor of Dendera. ${ }^{41}$ This raises the question of the date of the bowl, which might well have been manufactured earlier than the two preserved inscriptions would indicate. An uninscribed convex-sided bowl with an incurved rim found in a tomb at Abydos dating to the Early Dynastic Period (Figure 6) is an example of the type of vessel that the Metropolitan's fragment may have come from. ${ }^{42}$ In this scenario such a bowl could have been reused in the $\mathrm{Old}(?)$ and later in the early Middle Kingdom. The vessel's material and shape also suggest that it was not used in a daily ritual or in a mundane way but was rather deposited as a votive or commemorative object in a sanctuary or in a temple magazine.

Looking at the name on the outer surface of the fragment, then, one might reconsider Winlock's reconstruction and seek another possibility. In the incomplete Horus name only the two $t 3$ signs are preserved, and they are positioned in the center of the panel, leaving no space to the left or right for further signs. The only space for completing the Horus name is to be found above t3.wy. In proposing his reconstruction Winlock (see Figure 3) obviously assumed that the height of the cartouche (which is almost completely preserved) 
should correspond to the height of the Horus name. Such an assumption of course constrains the space for other signs above $t 3 . w y$, and Winlock must have felt that only the $n b$ basket (Gardiner sign list V30) fit the available place. Winlock's proposal remains a possibility, but it is not the only solution.

One characteristic of the royal protocols of nearly all the rulers of the Eleventh Dynasty is the use of the word t3.wy. For the present discussion, however, all of the Antef-kings, Montuhotep-Nebhepetre's first Horus name (Ś.'nh-ib-t3.wy), and Montuhotep-Seankhkare's Horus name (Ś.'nh-t3.wy.f) can be excluded. In the last phase of his long reign MontuhotepNebhepetre adopted the Horus name Sm3-t3.wy. While the name is commonly written with the $s m 3$-sign next to the t3.wy (seen for instance on the pillars of the lower colonnade of his mortuary temple), ${ }^{43}$ a second form exists as well. On numerous monuments and especially smaller objects the $s m 3$-sign has been put on top of the $t 3 . w y$ in order to adapt to spatial requirements. ${ }^{44}$

Even more important here, a large number of examples of royal protocols clearly demonstrate that the height of the cartouche need not always equal the height of the Horus name in inscriptions where the two are juxtaposed (see Figure 7). Especially when one looks at smaller carvings in stone and other materials (such as ivory), it becomes obvious that a slightly taller Horus name was actually the more common occurrence. ${ }^{45} \mathrm{~A}$ small Egyptian alabaster tablet discovered in the foundation deposit in the southeast corner of Montuhotep-Nebhepetre's mortuary complex at
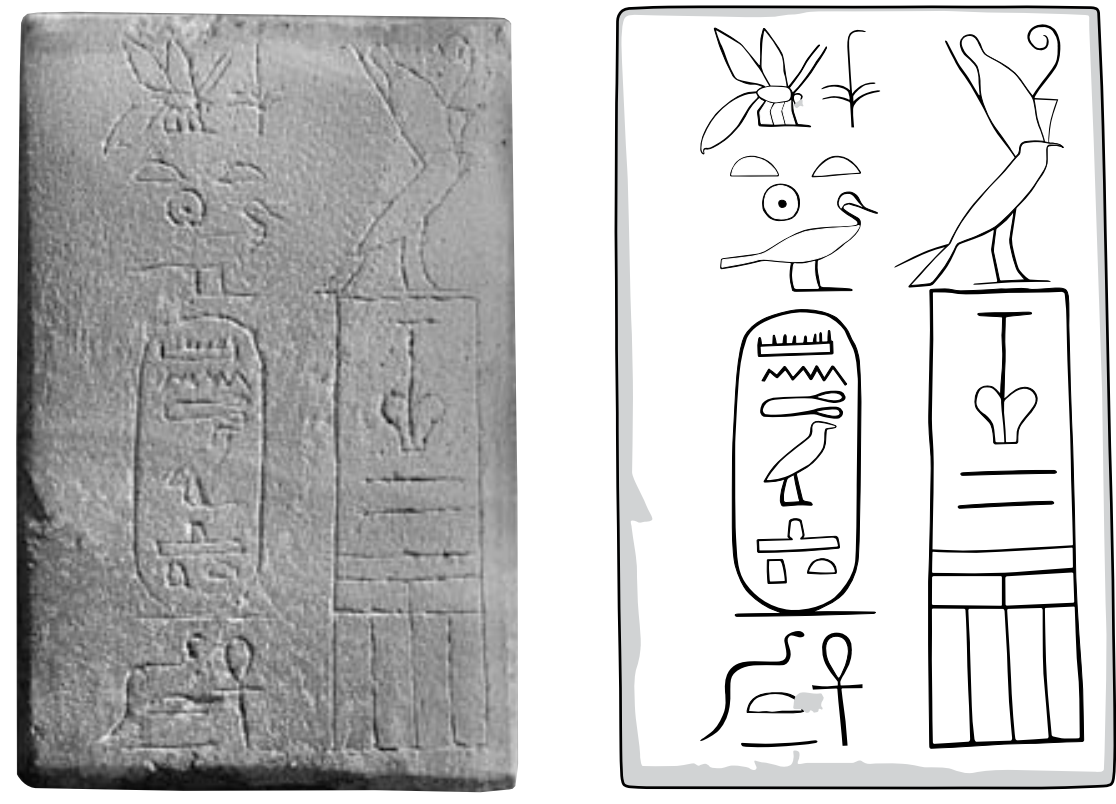

Deir el-Bahari (Figure 8) displays a fine example of such writing from that reign. ${ }^{46}$

The available space within the Horus name on the Lisht bowl can therefore be extended, which permits another reconstruction of the royal name. Since there is also no need to assume that the two inscriptions on the slate fragment must be chronologically close, I propose that it was actually Montuhotep-Nebhepetre's third and last Horus name-Sm3-t3.wy - that was once written on the outside of the slate bowl (see Figures 9, 10). Considering this king's
8. Tablet. From the southeast foundation deposit of Montuhotep-Nebhepetre's temple at Deir el-Bahari, Thebes. Egyptian, Dynasty 11, ca. 2051-2000 B.C. Egyptian alabaster, $27 / 8 \times 17 / 8$ in. (7.25 x $4.65 \mathrm{~cm})$. The Metropolitan Museum of Art, Rogers Fund and Edward S. Harkness Gift, 1922 (22.3.188). Drawing: Liza Majerus

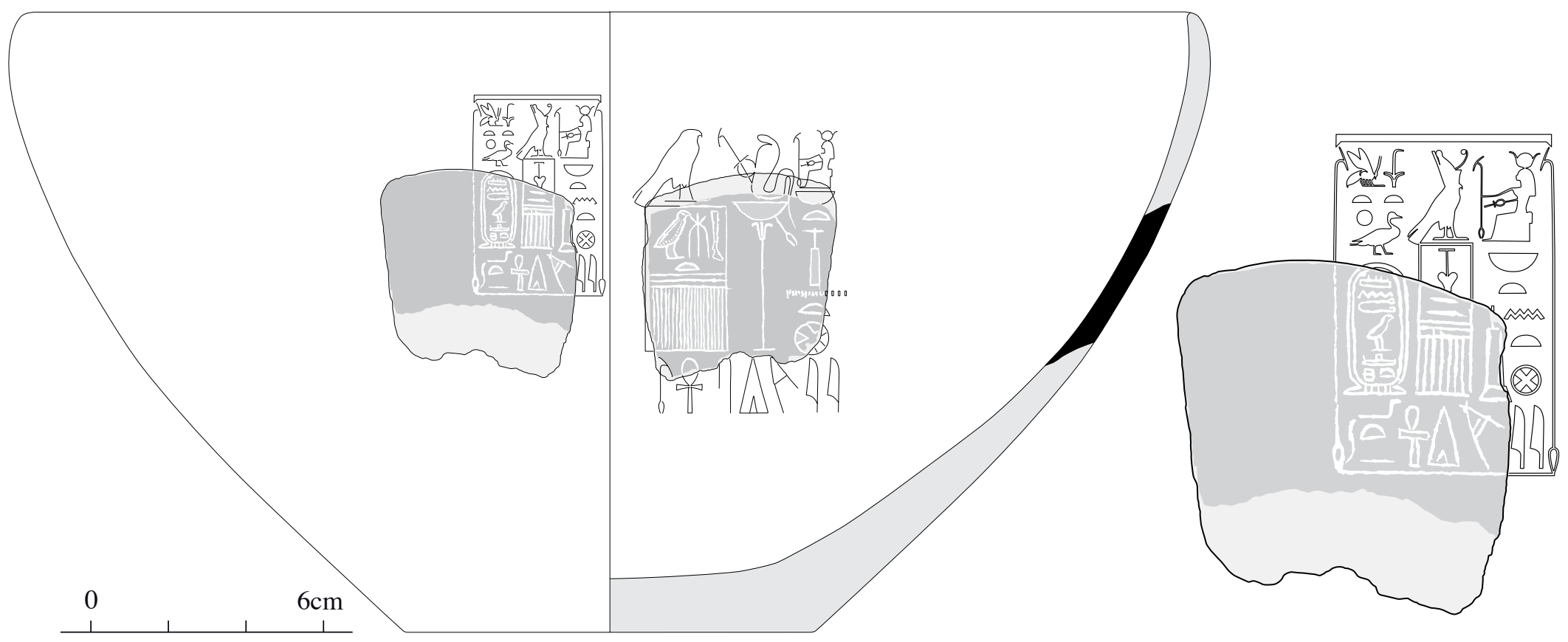

9. Reconstruction of the slate bowl from which the fragment in Figure 2 originated, with the inscriptions restored. On the outside of the fragment is inscribed the protocol of "[Horus Sema]tawy, the king of Upper and Lower Egypt, the son of Re, Montuhotep" and on the inside, that of "Horus Wehem-mesut" (Amenemhat I). In both texts the royal names face the text "beloved of Hathor, mistress of Dendera." Drawing: Liza Majerus, after William Schenck in Dorothea Arnold 1991, fig. 17
10. Reconstruction of the inscription on the outside of the slate bowl fragment in Figure 2. Drawing: Liza Majerus 


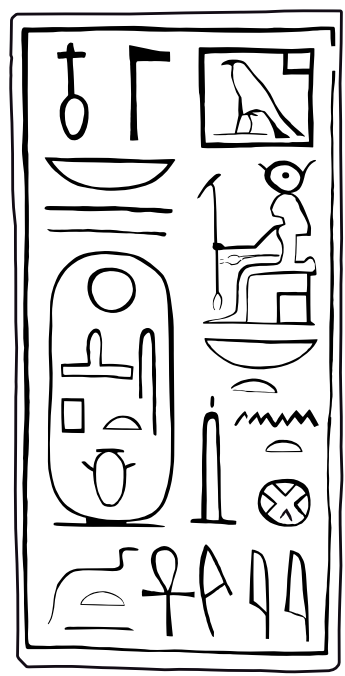
$5 \mathrm{~cm}$

11. Line drawing of a tablet showing the titles and throne name of Amenemhat I with the goddess Hathor, mistress of Dendera. Probably from a foundation deposit for a sanctuary or temple building at Dendera. Faience, $55 / 8 x$ $23 / 4 \times 3 / 4$ in. $(14.3 \times 6.9 \times$ $2 \mathrm{~cm})$. The piece, formerly in the Freiherr Wilhelm von Bissing Collection and later housed in the Egytian National Museum in Berlin (17567), is now in the Staatliche Sammlung Ägyptischer Kunst, Munich (Äs 2926) Drawing: Liza Majerus importance in Egyptian history as the unifier of the country after the turmoil of the First Intermediate Period and noting his ambitious building program, especially favoring the goddess Hathor of Dendera (see Figure 11), it seems more reasonable to propose that Amenemhat I might have specially wished to add his own name to a bowl inscribed with Montuhotep-Nebhepetre's name. ${ }^{47}$

Both kings left a considerable number of records at Dendera testifying to their devotion to Hathor. ${ }^{48}$ In the decoration of his small Ka-Chapel built near the temple of that deity, Montuhotep-Nebhepetre presented himself as the son of Hathor (Figure 12). ${ }^{49}$ The same monarch transferred the cult of this goddess to Gebelein (3rd Upper Egyptian nome), where he was also shown as her son. ${ }^{50}$ In the inscriptions at both places Montuhotep-Nebhepetre incorporated the epithet "Son of Hathor, Mistress of Dendera" in his cartouche to stress his special association with the goddess. Furthermore, it has been rightly supposed that somewhere in the Bay of Deir el-Bahari at Thebes an old sanctuary of Hathor must have existed that influenced Montuhotep-Nebhepetre to build his funerary monument there, thus initiating largescale veneration of the deity in the Theban area. ${ }^{51}$

From the beginning of Egyptian history Hathor was a central figure in the ideology of Egyptian kingship. She was the divine consort and mother of the monarch. ${ }^{52}$ Although little remains from Amenemhat I's building program in Upper Egypt, ${ }^{53}$ inscribed blocks found at Dendera amply attest the monarch's intention to enhance the prominence of Hathor's cult. ${ }^{54}$ The faience tablet inscribed with the titles and the throne name of this king as beloved by Hathor, Mistress of Dendera (Figure 11) provides good reason to believe that Amenemhat I erected a sacred building at Dendera. ${ }^{55}$ Although the provenance of the small votive object is unknown, it is quite likely that it was an element of a foundation deposit for a sanctuary or temple building at Dendera. ${ }^{56}$ That the form of the writing on the tablet adheres to the standards of inscribed foundation tablets of that time provides further confirmation of the reconstruction put forward here.

Being of humble birth and with no direct ties to the Egyptian monarchy, Amenemhat I would have been keen to demonstrate his adherence to the religious and ideological concepts of that monarchy, including the veneration of Hathor. In the middle of the first decade of his reign he left Thebes, the center of Dynasty 11 rule, and moved to the north of Egypt. ${ }^{57}$ When in the later part of his long reign he finally established a new capital, It-Towy, at el-Lisht, ${ }^{58}$ he must have realized the necessity of establishing the gods crucial to Egyptian kingship in his new city, where temples and sanctuaries would certainly have been built. Next to Hathor, who was already worshiped under a special form of the cow in the nearby site at Atfih $(T p-j h w)$, the capital of the 22nd Upper Egyptian nome situated about nine miles south of el-Lisht (in several inscriptions Hathor of Atfih is labeled as residing in the pyramid temple of Senwosret I, or Xnmtswt), ${ }^{59}$ Montu was one of the foremost male deities in the early Middle Kingdom pantheon. ${ }^{60}$ Amenemhat I not only established those cults but in all likelihood furnished them with all sorts of equipment and goods from various parts of the country. A finely carved limestone relief block was retrieved from his pyramid temple that shows the monarch embraced by Montu, "the Lord of Thebes." ${ }^{61}$ And two altars dedicated to Amen-Re and Montu were inscribed by Amenemhat I's son and successor, Senwosret I. ${ }^{62}$

Amenemhat I probably also transferred to his new capital and reused votive or sacred objects from important places such as Dendera and perhaps other sites. It seems understandable that for this purpose Amenemhat I would have been especially interested in objects inscribed by the unifier of the country, King Montuhotep-Nebhepetre. This monarch, like Amenemhat I himself, originated from a local family with absolutely no direct links to the Memphite kingship of the Old Kingdom and needed therefore to bolster his claim to the throne with both ideology and force. ${ }^{63}$ Montuhotep-Nebhepetre's success and long reign certainly created a strong impetus for the founder of the Twelfth Dynasty to associate himself with his predecessor's achievements and to continue that monarch's veneration of the most important gods, including Hathor of Dendera, in order to strengthen his own claims. ${ }^{64}$

Among the many objects in the Egyptian Art Department of the Metropolitan Museum that date from the reign of the founder of the Twelfth Dynasty is a small rectangular Egyptian alabaster tablet incised with a text consisting of three vertical columns (Figure 13). ${ }^{65}$ This tablet, which has been repeatedly mentioned in the scholarly literature but has never been published, relates directly to the discussion presented here and might also initiate further research on the subject. The tablet's place of origin is unknown, but since its inscription mentions the god Montu, Lord of Thebes, the tiny object most probably came from Luxor. This presumption seems to be corroborated by another tablet of the same size and material and carrying a similar inscription (Figure 14). This tablet was bought from the Luxor-based dealer Mohareb Todrus, ${ }^{66}$ along with other objects, for the Ägyptisches Museum und Papyrussammlung in Berlin on January 18, 1905. ${ }^{67}$ The Berlin tablet and its counterpart in New York are so similar in size, form, and epigraphy that they no doubt belonged to the same issue and very likely originated from the same place. ${ }^{68}$ As each tablet names Montu, the Lord of Thebes, it can be safely surmised that they came from a foundation deposit of a building dedicated to Montu at Thebes. Whether the tablets came from a sanctuary at Karnak, ${ }^{69}$ from another place on the east bank, 
or were used in a building on the west bank (perhaps the place south of the Deir el-Bahari bay that was originally intended as the king's burial spot) remains an open question, however. ${ }^{70}$ Both tablets show three columns of vertical inscriptions created by two vertical dividing lines, and, as is usual with this type of Egyptian alabaster object, there is no surrounding frame (see Figure 8). The inscriptions are fairly well carved with semicursive hieroglyphs, some of the signs being rendered in the somewhat clumsy form characteristic of this kind of votive object. ${ }^{71}$ The column on the right contains the god's name and epithet and faces left, while the other two columns with the names and epithets of the king are turned right, confronting the deity. ${ }^{72}$ The text on the New York tablet reads:

$H r$ Whm-mswt nb t3-wj nswt bjt 'Imn-m-h3t dj 'nh nb $\underline{d} t$ $m r j$ Mntw nb W3ś.t (The Horus Wehem-mesut, Lord of the two lands, the King of Upper and Lower Egypt, Amenemhat, given all life forever, beloved of Montu, Lord of Thebes).

The text on the tablet in Berlin reads:

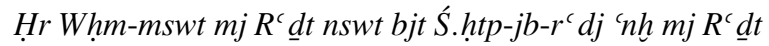
$m r j$ Mntw nb W3ś.t (The Horus Wehem-mesut, [given life] like Ra forever, the King of Upper and Lower Egypt, Sehetepibre, given life like Re forever, beloved of Montu, Lord of Thebes).

In both cases the name of Thebes is written not with the nome sign but with the town determinative, indicating that

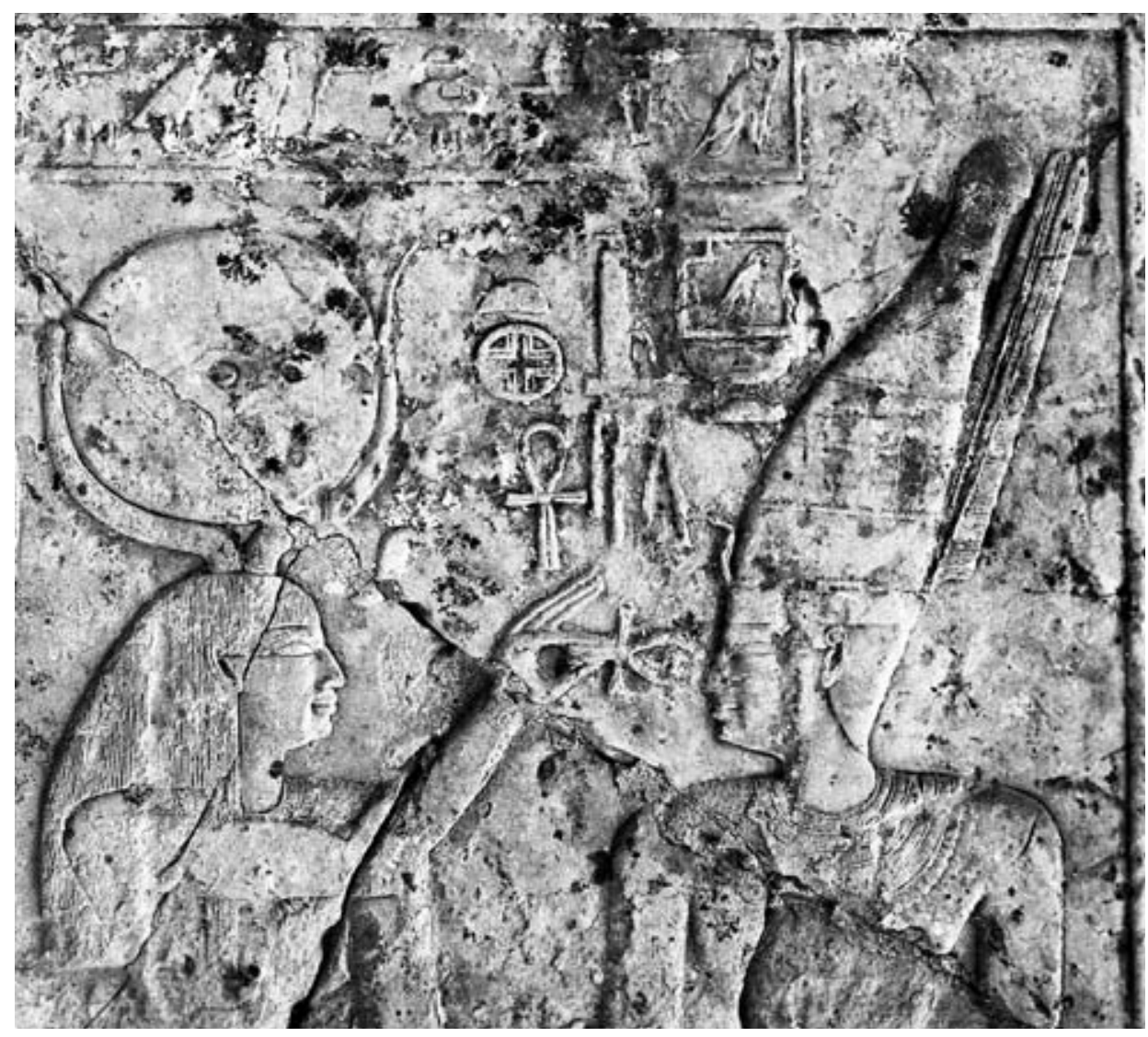

12. Detail of a limestone relief showing the goddess Hathor of Dendera presenting life to King Montuhotep-Nebhepetre. From the Ka-Chapel of Montuhotep-Nebhepetre near the temple of Hathor, at Dendera. Museum of Egyptian Antiquities, Cairo (JdÉ 46068). Photograph: Archive of the Department of Egyptian Art, MMA (C-335)
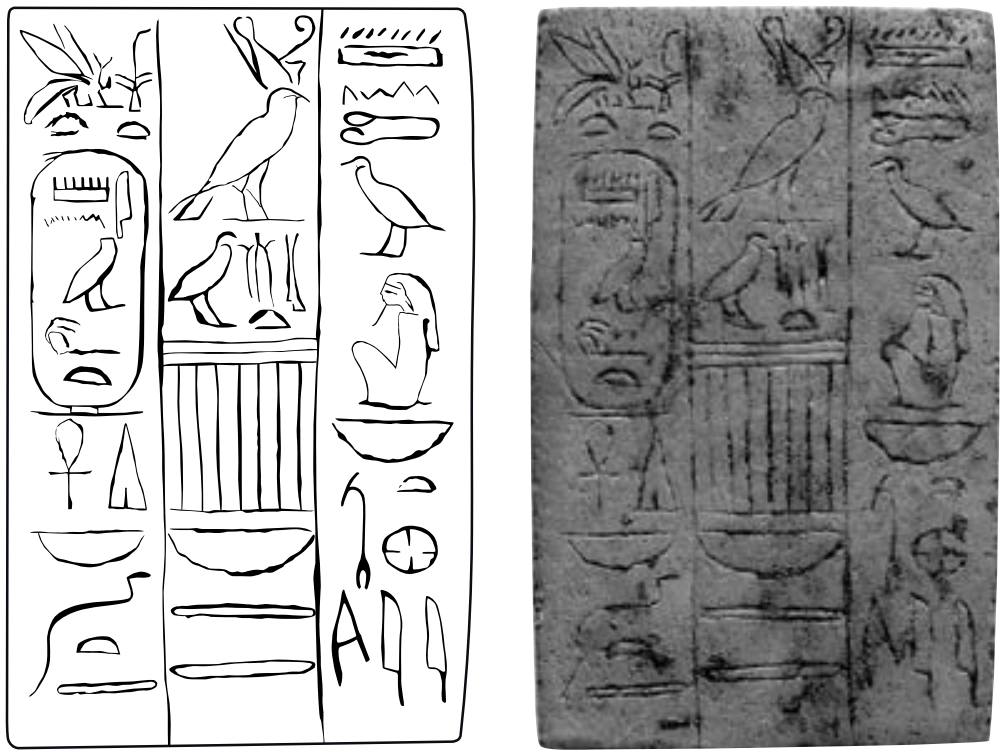

13. Tablet with the names of Amenemhat I and Montu, the Lord of Thebes. Probably from Luxor. Egyptian, Dynasty 12, reign of Amenemhat I, ca. 1991-1962 B.C. Egyptian alabaster, $31 \frac{118}{8} 2 \times 5 / 8$ in. $(8 \times 5 \times 1.5 \mathrm{~cm})$. The Metropolitan Museum of Art, Theodore M. Davis Collection, Bequest of Theodore M. Davis, 1915 (30.8.247). Drawing: Liza Majerus
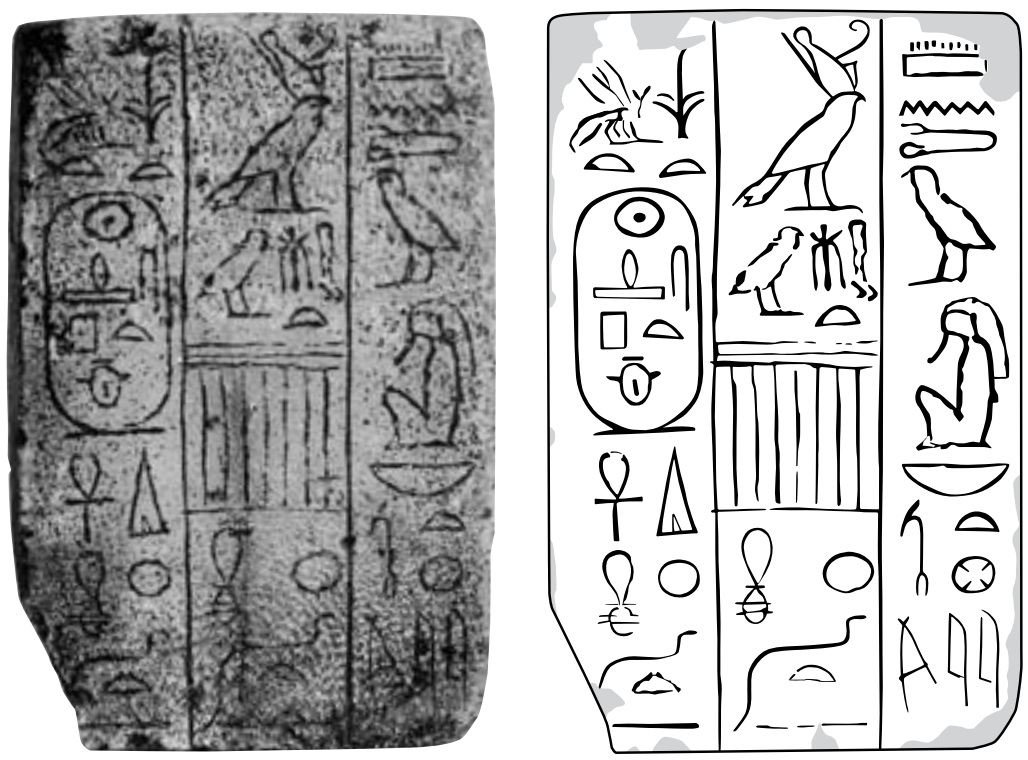

14. Tablet with the names of Amenemhat I and Montu, the Lord of Thebes. Probably from Luxor. Egyptian, Dynasty 12, reign of Amenemhat I, ca. 1991-1962 B.C. Egyptian alabaster, $3 \frac{118}{8} 2$ in. $(8.1 \times 5.1 \mathrm{~cm})$. Ägyptisches Museum und Papyrussammlung, Staatliche Museen zu Berlin ( $\ddot{M}$ 17567). Drawing: Liza Majerus 
it was Montu in the town of Thebes for whom the building was erected. ${ }^{73}$ The tablets show slight variations in the composition of the text in the two left-hand columns, especially in the use of the epithets after the king's names. Curiously, the monarch's nswt-bjt-name is given on the New York tablet as 'Imn-m-h3t and on the one in Berlin as S.htp-jb-rc. ${ }^{74}$ Also noteworthy is the way the king's serekh is rendered. The panel containing the Horus name is not drawn as an independent unit, but the way in which the two vertical lines dividing the three columns constitute its outer frame makes it the center of the three-columned inscription. ${ }^{75}$ Furthermore, the top border of the serekh is omitted on both tablets, thus leaving the falcon without the usual baseline. This correspondence in epigraphy is certainly no coincidence, and it corroborates the shared identity and origin of the two pieces. There can be no doubt that more tablets of this sort once existed, and it will remain a goal of future endeavor to identify the building to which these votive objects once belonged.

\section{ACKNOWLEDGMENTS}

I thank Dorothea Arnold, Lila Acheson Wallace Chairman of the Department of Egyptian Art of The Metropolitan Museum of Art, for our many fruitful discussions on early Middle Kingdom history and art and for very kindly giving me permission to publish the objects housed in the department that pertain to the topic of this article. I also extend my sincere thanks to Isabel Stuenkel for her tireless help in the department's archive, William G. Barrette for his professional photographs, and Liza Majerus, who prepared most of the line drawings for this article. For corrections in the English text I am deeply indebted to Dorothea Arnold and Marsha Hill, curator of Egyptian art at the Metropolitan.

\section{NOTES}

1. The numbering of the Theban rulers (Dynasty 11) called Montuhotep is still inconsistent. While most scholars start with MontuhotepHrw tpj-' as the first potentate of this name, others (see, for instance, Werner 2001) prefer to attribute this position to Montuhotep-Nebhepetre. In this article the first version is followed, with four rulers carrying this name.

2. Winlock 1941; Simpson 1959, pp. 26-28; Barta 1970, pp. 34-37; Helck 1981, pp. 102-3; von Beckerath 1982, pp. 69-70; Gestermann 1987, pp. 31-33; Vandersleyen 1995, pp. 37-39, 43-44; von Beckerath 1997, pp. 139-42; von Beckerath 1999, pp. 80-81, 284; Schneider 2002, p. 158. For the royal protocol of that monarch and the historical sources, see the fundamental study by Lilian Postel (2004, pp. 265-78, 371-77).

3. Breasted 1906, sects. 434ff.; Couyat and Montet 1912, pls. 3, 11, 29, 36, 37 (nos. 1, 40, 55, 105, 110, 113, 191, 192, 205, 241); Fakhry 1952, pp. 19-23, figs. 14-19, pls. 6-8A; Goyon 1957, nos. 52-60; Schenkel 1965, pp. 260-70; Gundlach 1980; Seyfried 1981, pp. 1, 7-10, 115, 245-47, 258, 262; Posener-Kriéger 1989, p. 313.
Recently, a representation of the king with a short text mentioning an expedition in year one of his reign was found at Ain el-Soukhna; see Abd el-Raziq 1999, p. 129, pl. 33, and Abd el-Raziq et al. 2002, pp. 40-41, figs. 10,11 , pls. 48-52.

4. Winlock 1943, pp. 281-83. Based on textual evidence recording only years one and two of Montuhotep-Nebtawyre's reign, it is generally assumed that it did not exceed those two years. The much-debated record of a first heb-sed ( $z$ t tpj $h b-s d$ ) in the king's second year (Hammâmât No. 110) is unlikely to reflect historical truth. Some scholars doubt that the mention of the first heb-sed and the mining inscription are contemporaneous; see Hornung and Staehelin 2006, pp. 9, 19, 36. Be that as it may, in the monarch's second year an expedition of 10,000 men was sent to the quarries in the Wadi Hammâmât to obtain a sarcophagus, and 3,000 men were dispatched to get a lid for the king's burial (Hammâmât Nos. 110, 191, 192). The mission was led by the vizier Amenemhat (commonly assumed to be identical with Montuhotep-Nebtawyre's successor, King Amenemhat I), and the items were brought back into the Nile Valley "without a loss" (Hammâmât No. 113). The high number of participants mentioned in the texts, however, is puzzling and has to be met with reservation. There is no way that 10,000 men were necessary in order to obtain a sarcophagus from the quarries. According to inscription No. 192, the lid, measuring 8 by 4 by 2 cubits $(4.2 \times 2.1 \times 1.05 \mathrm{~m})$, was brought to Egypt ( $t 3$-mrj) by 3,000 men. These high numbers must be regarded either as exaggerations, intended to glorify Amenemhat's success as leader and organizer of the expeditions, or as an indication that the vizier had an actual political reason to keep such a force close at hand.

5. Müller 2005, pp. 57, 59.

6. See Dorothea Arnold 1991, pp. 16-17.

7. On a relief block from a building erected by Amenhotep I at Karnak, King Montuhotep-Seankhkare is immediately followed by the jtj-ntr $\dot{S} n$-wsr.t (without a cartouche), who is commonly regarded as Amenemhat I's nonroyal father (Chevrier 1938, p. 601; Habachi 1958, pp. 185-90, pl. 4; Posener 1956, pp. 50-51). The only "official" monument probably recording his existence is the so-called Chamber of Ancestors built by Thutmosis III at Karnak, where Nebtawyre is supposed to have been recorded after King Nebhepetre and a King "Seneferkare," commonly restored to Seankhkare (Sethe 1914, p. 609[16]; Vandier 1936, pp. 106-7; von Beckerath 1965, p. 8; Gomaà 1980, p. 136 and n. 5; von Beckerath 1999, pp. 80-81; Postel 2004, p. 266). Although it is generally agreed that the order of royal names preserved in the Karnak list is selective and not in chronological order (see Maspero 1901, p. 281; Maspero 1902, p. 189; Habachi 1958, p. 182; Wildung 1969, pp. 60-63; Redford 1986, p. 31; and von Beckerath 1997, p. 23), it is nevertheless assumed that the name incompletely preserved and following King "Seneferkare" (Seankhkare?) must be restored as $[N b]-t 3[w y]-R^{c}$.

8. On the word wsf in the royal canon, see Ryholt 1997, pp. 10-12, and Ryholt 2006, p. 30.

9. See Winlock 1947, p. 57, and Hayes 1964, pp. 31-34; discussed in Berman 1985, pp. 17-18, and Seidlmayer 2006, pp. 159-61. It is not possible to decide if those seven years comprised the entire length of Montuhotep-Nebtawyre's reign (von Beckerath 1965, p. 8) or if a period of turmoil and political unrest unfolded after his second year and was ended only when Amenemhat I seized power and the Egyptian throne. A number of royal names known only from Lower Nubia are regarded as the names of antikings (Gegenkönige) at the end of Dynasty 11 by some egyptologists (see Stock 1949, pp. 84-85; von Beckerath 1965, p. 8; von Beckerath 
1997, pp. 141-42; and von Beckerath 1999, pp. 80-81). On these kings, see the cautious discussion by Postel (2004, pp. 266-67, 279-80, 379-81).

10. Couyat and Montet 1912, pl. 36; Winlock 1941, pp. 116-17; Winlock 1943, p. 282; Stock 1949, p. 89; Hayes 1953, p. 167; Habachi 1958, p. 189; Gundlach 1980, p. 114; Callender 2000, p. 156.

11. Montuhotep-Nebtawyre's filiation as recorded in the Hammâmât inscription fits well the protocol of Egyptian kingship at that time and cannot be used as an argument for his illegitimacy; see Roth 2001, pp. 192, 198-201. In the famous Wadi Shatt er-Rigale scene depicting Montuhotep-Nebhepetre with his mother Jah (Winlock 1947 , p. 62, pls. 12, 36; Habachi 1963, p. 48, fig. 23), she is also labeled only as "king's mother." As has been recently demonstrated by Postel (2004, pp. 269-71), Nebtawyre's titulary does not indicate any disruption in the succession of the late Eleventh Dynasty.

12. See, for instance, von Beckerath 1997, p. 139. While Hayes (1953, p. 167) seems initially to have favored the usurpation theory, he later changed his opinion; see Hayes 1964, p. 31, where he clearly admitted that "there is no evidence that the new ruler was a usurper, the omission of his name from the Turin Canon and other Ramesside lists of kings being attributable, . . . to a gap in the document used as a source by the compilers of these lists." See also von Beckerath 1965, p. 8, and Barta 1970, pp. 47-48. Although Stock knew of Winlock's 1941 article on the slate bowl fragment, he nevertheless disregarded his comments and concluded his chapter on the end of the Dynasty 11 (Stock 1949, p. 90) with the words: "Amenemhet I. liess offenbar seinen ehemaligen Herrn und Gegner zur Vergessenheit verurteilen und unterband dadurch dessen Aufnahme in die staatlichen Listen der Könige." Amenemhet I apparently condemned his former master and opponent to oblivion and thereby prevented his inclusion in the state king lists. As Helck (1956, p. 33) correctly pointed out, the omission of Horus Nebtawy from the later lists cannot be taken as an argument for his suppression or for an assumed illegitimacy, since the lists do record condemned kings and antikings ("verfemte Herrscher und Gegenkönige").

13. Hayes 1953, p. 167, fig. 102.

14. For the reconstruction of the complete bowl, see the drawing by William Schenck in Dorothea Arnold 1991, p. 12, fig. 17, and p. 43n51.

15. Winlock 1941, pp. 116-19. It remains a mystery why this little object, which entered the Metropolitan's Egyptian collection in 1909, received so little attention. Not only is the year of its discovery not recorded (1907 or 1908?) but the exact find spot in the area of Amenemhat I's pyramid complex is also undocumented. According to Dorothea Arnold, tiny scratches and marks on the edges of the fragment indicate that it was later, probably during the so-called village period (see note 27 below), reused as a tool to prepare smooth surfaces, for instance papyri.

16. Ibid., p. 117nn2-3.

17. Ibid., p. 117: "There is very small likelihood that an object of so little intrinsic value would have survived the twelve years of S'ankh-ka-Re' to be brought to Ithtowe, King Amen-em-het's new capital at Lisht, and naturally far less likelihood that it had already survived the fifty-one years of Neb-hepet-Re'. Therefore, this bowl must have been later than both of these Eleventh Dynasty rulers, and thus King Nebtawi-Re', its first owner, must have been among their successors. Further, the linking of the two names on it suggests that Neb-tawi-Re' was an immediate predecessor of Amenem-het I, the founder of the Twelfth Dynasty." See also Winlock 1947 , p. 54.
18. Winlock 1941, p. 117

19. Ibid., p. 118; Winlock 1947, p. 54.

20. Winlock 1947, p. 54.

21. Ibid.; Hayes 1953, p. 176.

22. Winlock 1947, p. 54.

23. Von Beckerath 1965, p. 8. The earlier form of King Amenemhat I's titulary (Horus Sehetepibtawi, Nebty Sehetepibtawi) is preserved on an altar found at Sebennytos (now in the Alexandria National Museum, no. 460); see Daressy 1904, pp. 124-25; Dorothea Arnold 1991, p. 9, fig. 8; and Postel 2004, pp. 280-89, 377. In order to strengthen his argument, von Beckerath also referred to the glazed tablet (Figure 4, and see note 27 below), but he was obviously misled by Hayes's wording (1953, p. 176) linking the glazed tablet and the slate fragment as if they were found together, or at least in close archaeological context, at Lisht-North: "Other monuments from the pyramid site associated directly with Amunem-het I include ... several fragments of blue faience tiles with the inscriptions in relief, possibly from the foundation deposits. With the latter was found a fragment of faience inlay bearing part of the cartouche of a King Montu-hotpe [sic; and without indicating that the first part of the name is missing], probably Neb-towy-Re', Amun-em-het's immediate predecessor." Compare von Beckerath 1965, p. 8n3: "Ausserdem wurde in Lischt unter Fayence-Kacheln mit dem Namen Ammenemes' I. auch eine solche mit der Kartusche eines Montehotpe, wahrscheinlich $N b$-t $3 w j-R^{\varsigma}$, gefunden." (Among faience tablets with the name Ammenemes' I discovered at Lisht there was one with a cartouche of Montehopte, probably ... . ) Although the archaeologists found a considerable number of broken glazed faience tablets, none of them can be linked directly with any of the three foundation deposits uncovered in Amenemhat I's pyramid precinct (on these deposits, see Mace 1921, pp. 16-17, figs. 8-11; Hayes 1953, p. 175; Simpson 1954, pp. 16-21; and Weinstein 1973, pp. 66-69). The fragments were retrieved from the radim of the so-called village period (see note 27 below). Thus, any connection between the [ ]hotep fragment (Figure 4) and the slate piece (Figure 2) rests solely on the interpretation of the latter. In consequence, the two incomplete inscriptions led Hayes and von Beckerath to believe that the founder of the Twelfth Dynasty regarded himself as the legitimate heir of the preceding dynasty in respecting the monuments of his predecessors. See von Beckerath 1965, p. 8: "Wir finden hier [on the slate fragment] sogar die Namen der beiden Herrscher in enger und anscheinend beabsichtigter Verbindung" (We here . . . even find the names of the two rulers in close and seemingly deliberate association).

24. Von Beckerath (1965, p. 9) further speculated that Amenemhat I changed his old name (preserved on the altar from Sebennytos; see note 23 above), which was shaped according to the protocol of the Dynasty 11 monarchs, after Montuhotep-Nebtawyre's death and the start of his sole reign. The political constellation of having two monarchs ruling the country consequently became the prototype for almost all rulers of the following dynasty. Although I do not question the institution of coregency during the Twelfth Dynasty, von Beckerath's reasoning is not convincing, since none of the monarchs of that dynasty, who initially shared their power with their fathers, later changed their names after the older king had died. The change of Amenemhat I's name must have had a political purpose more serious than the death of his predecessor.

25. See for instance Schneider 2002, p. 53.

26. Von Beckerath 1965, p. 8; Helck 1981, pp. 102-3; Gestermann 1987, pp. 32-33.

27. The fragment was found with many other fragments in the radim (debris) of the "village period," dating to the late Middle Kingdom 
or even the New Kingdom according to the photograph register of the MMA Egyptian Archives (Exped. Neg. No. L 13-14: 610). 28. See Dieter Arnold 1979, fig. 12, and Postel 2004, pp. 319-55. 29. Von Beckerath 1982, p. 70; von Beckerath 1999, pp. 102-5.

30. See Spalinger 1984 and von Beckerath 1999, pp. 90-105. A later note on the "tomb card" for MMA 15.3.916 records that the incomplete name should be reconstructed with the pedestal and a recumbent crocodile on top, reading the name as King [Sobek-]hotep.

31. Winlock 1941, p. 117.

32. Murnane 1977, pp. 23-24.

33. See Dorothea Arnold 1991, p. 15.

34. Allen 2003, pp. 22-23.

35. See Simpson 1959, p. 27; Dorothea Arnold 1991, p. 15.

36. In the Amenemhat I inscription the verb $m r j$ can be reconstructed according to the outside text as $[H r] W h m m s w t$ [di] ' $n \underline{h}[\ldots d t$ ? ] [mry] [hwt-hrr n]bt'Iwn[t].

37. See the remarks below and the two Egyptian alabaster tablets of Amenemhat I (Figures 13, 14).

38. See note 72 below.

39. See, for example, the Egyptian alabaster sistrum inscribed with the name of King Teti (Dynasty 6) in the MMA (26.7.1450; see Hayes 1953, fig. 76, and Fischer 1968, frontis.).

40. Winlock 1941, p. 117.

41. See Fischer 1968, 52-54.

42. For this vessel type, see Aston 1994, pp. 111ff., fig. 10(50).

43. Naville 1907, pls. 8, 7H.

44. See Postel 2004, p. 190. Although the present list is certainly incomplete, various monuments coming from different parts of Egypt exhibit the vertical writing: the fragments of an altar from Medamud (Bisson de la Roque, Clère, and Drioton 1928, p. 52, figs. 34, no. 467, 143, no. 3124; Bisson de la Roque 1931, pp. 56-57, fig. 30, inv. 5414); one of the Egyptian alabaster tablets found in Deir el-Bahari (MMA 22.3.188; Dieter Arnold 1979, pp. 55-56, fig. 12, pl. 31); two doorjambs from Tod (inv. 2121, 1171; Bisson de la Roque 1937, pp. 69-70, figs. 22, 31); the lower part of a granite statue from Tod (no. 1510; Bisson de la Roque 1937, pp. 77-79, fig. 31); a limestone doorjamb and wall fragments from Elephantine (Habachi 1963, figs. 18, 19, pl. 13; Kaiser et al. 1975, pls. 21b, 22a).

45. Among the many examples from the Old Kingdom are Unas's small Egyptian alabaster vessel in the Brooklyn Museum (inv. 37.76E; James 1974, pp. 20-21, no. 53, pl. 23); Teti's Egyptian alabaster sistrum (MMA 26.7.1450; see note 39 above); Merenre's ivory box (Louvre N 794; Ziegler in Dorothea Arnold et al. 1999, p. 450, no. 181); Pepi I's Egyptian alabaster vessel from his pyramid precinct (Berlin 7715; Priese 1991, p. 42, no. 27); Pepi II's small Egyptian alabaster jubilee jar (Louvre N648a,b; Ziegler in Dorothea Arnold et al. 1999, pp. 448-49, no. 180); and Pepi II's ivory headrest (Louvre N646; ibid., pp. 452-53, no. 183).

46. Hayes 1953, p. 155, fig. 92; Dieter Arnold 1979, pp. 55-56, fig. 12, pl. 31.

47. See Dorothea Arnold 2008, pp. 5-6.

48. Fischer 1968, p. 52 and n. 209. The importance of Dendera during the Eleventh Dynasty was discussed by Gundlach (1999, pp. 31-33, 40-41).

49. Habachi 1963, pp. 19-28; O'Connor 1999, pp. 215-20.

50. Porter and Moss 1937, p. 163; Donadoni-Roveri, D'Amicone, and Leospo 1994; Marochetti 2005; Morenz 2009.

51. Allam 1963, pp. 57-62; Dieter Arnold 1974, pp. 83-84. In the temple on top of the Mountain of Thot, to the west of Thebes, cult objects and epigraphical evidence testify to Hathor's veneration during the time of Montuhotep-Nebhepetre's successor, Seankhkare (see Pudleiner 2001).
52. Allam 1963; Troy 1986, pp. 53-72; Radwan 2006. In his prayer recorded on a stela in the MMA (13.182) King Antef Wah-anch addressed Re-Atum and Hathor; see Winlock 1947, pl. 4, and Clère and Vandier 1948, pp. 9-10.

53. On the king's building program in Egypt, see Gestermann 1987 pp. 119-20, 133-34, ill. p. 125, and Hirsch 1994

54. Fischer 1968, p. 52n209. For a discussion of the fragments with further references, see Hirsch 2004, pp. 16, 183-84 (docs. 36-40). Thus far two lintels made of red granite, a granite block with an inscription found on the roof of the Ptolemaic building and used as a water drain, a sandstone column with the cartouche of Amenemhat I(?), a block with the inscription "beloved of Hathor, mistress of Dendera, son of Ra Amenemhat, given life," and a faience foundation plaque (Figure 11; see von Bissing 1932, 68-69) have been found.

55. Von Bissing 1932, p. 69, ill.; Weinstein 1973, p. 70, no. 11; Staatliche Sammlung Ägyptischer Kunst 1976, p. 59.

56. The fact that Amenemhat I erected a building at Dendera is indirectly corroborated by a bronze situla from the Late Period (Berlin inv. 18 492), which carries the same two lines of inscription that are preserved on the faience tablet (Schäfer and Andrae 1925, ills. pp. 299 (upper right), 602 (299,5). Amenemhat I was obviously venerated as one of the memorable builders of the Hathor temple at Dendera in the Late Period (Radwan 1983, p. 149).

57. For the chronology of Amenemhat I's reign, see Dorothea Arnold 1991.

58. The first inscriptional record mentioning the capital It-Towy dates from Amenemhat I's last year (year 30; Catalogue géneral des antiquités égyptiennes du Musée du Caire, stela 20516); see Simpson 1963, p. 53, and Dorothea Arnold 1991, p. 14.

59. See Allam 1963, pp. 92-93, and Gomaà 1987, pp. 44-45.

60. Werner 1985, pp. 22-77; Hirsch 1994, pp. 140-42.

61. Museum of Egyptian Antiquities, Cairo (JdÉ 40482). On another block (a door lintel: JdÉ 31877) Montu is labeled as Lord of the two lands and Atum, the lord of Heliopolis. A third block (JdÉ 40483) depicts Sokar, the lord of Ra-Setjau. All these blocks were found reused in the mortuary precinct at Lisht-North and in all probability originated from a sanctuary at It-Towy. The reliefs will be published in my forthcoming book The Pyramid Precinct of Amenemhat I at Lisht: The Reliefs (MMA).

62. The two objects were retrieved from a canal near el-Lisht; see El-Khouly 1978, Dieter Arnold 1988, pp. 14, 94n287, and Dorothea Arnold 1991, p. 15 and n. 53. On the possibility of a cult installation of Hathor at the pyramid precinct of Senwosret I at LishtSouth, see Dorothea Arnold 1991, pp. 17, 74, and Dorothea Arnold 2008, p. 5.

63. See Gestermann 1987, pp. 55-57, 224-25.

64. Dorothea Arnold 2008, p. 5. As Aufrère (1982, pp. 53-54) has pointed out, Amenemhat I's first Horus (and Nebty) name (Ś.htp-ib.t3.wy) is modeled not only on Teti's Horus name (Ś.htp-t3.wy), but also on Montuhotep-Nebhepetre's first Horus name (Ś. 'nh-ib.t3.wy). See also Postel 2004, pp. 285-86. Berman (1985, pp. 8-9) was somewhat skeptical about Aufrère's reasoning.

65. Hayes 1953, p. 179; Weinstein 1973, p. 70, no. 12; Hirsch 1994 p. 140; Hirsch 2004, p. 14; Ullmann 2007, p. 6n24. I thank Dr. Dorothea Arnold for drawing my attention to this important object.

66. Mohareb Todrus (died 1937) was the son of the antiquities dealer and consular agent in Luxor for Prussia Todrous Boulos (died 1898); see M. L. Bierbrier, ed., Who Was Who in Egyptology, 3rd ed. (London, 1995), p. 417.

67. The tablet was lost during World War II and was published only in a cursory sketch in Aegyptische Inschriften 1913, p. 212. For 
providing a photograph and the information pertaining to this object I am deeply indebted to C. Saczecki of the Staatliche Museen zu Berlin. According to the museum's inventory book the piece is said to originate from Karnak. For the kind permission to publish the tablet here I thank Olivia Zorn of the Berlin museum.

68. Contrary to Ullmann's statement (2007, p. 6n24) that the Amenemhat I tablets and their inscriptions are very similar to those found in Montuhotep-Nebhepetre's foundation deposits at Deir el-Bahari and the tablet naming Montuhotep-Seankhkare (see note 72 below), several divergences seem to indicate a kind of "development" in the production of Egyptian alabaster tablets. The tablets of Dynasty 11 belonging to this category of votive objects (Dieter Arnold's "second type"; see 1979, p. 56) show only two vertical lines of inscriptions, which are never divided by any intermediary line. The texts containing the god's and king's names uniformly face in the same (right) direction. Only the tablet of Seankhkare shows the "opposition" of the godly and the royal text facing each other, which seems to become a standard for the Middle Kingdom (see Figure 11) and the Senwosret I tablets found at Abydos (Petrie 1903, pl. 23, 68). In the latter examples the text is framed with two $w 3 s$-scepters, the sky, and the $t 3$-sign.

69. Although little remained of the building activities at Karnak before the reign of Senwosret I, the traces and objects that have been preserved clearly show that the last monarchs of the Eleventh Dynasty and Amenemhat I were interested in that area (see Hirsch 2004, pp. 13, 180-82, and Gabolde 2009, especially p. 107).

70. See Dorothea Arnold 1991. Since the eastern part of MontuhotepNebhepetre's mortuary complex at Deir el-Bahari was dedicated to the cult of Montu (see Dieter Arnold 1974, p. 75; 1979, p. 56; and 1997, p. 74), it is feasible to assume that Amenemhat I intended to incorporate this important deity in his burial complex as well.

71. Compare the inscribed tablets of Montuhotep-Nebhepetre and Senwosret I (Dieter Arnold 1979, fig. 12, pl. 31, and 1988, fig. 37, pls. 60c, 61c, 62d, 63a, b).

72. The vertical columns of text facing each other are absent on the Montuhotep-Nebhepetre tablets (see Figure 8 and note 71 above), but they occur on the tablet and cylinder seal of MontuhotepSeankhkare (see note 68 above). The form of the inscriptions on the tablets from the southwest foundation deposit of Amenemhat I's pyramid differ entirely from the examples discussed here and belong to the group found in Senwosret I's pyramid (see Dieter Arnold 1988, fig. 37). The Amenemhat I tablets will be included in the forthcoming volume on the pyramid complex's architecture by Dieter Arnold (MMA).

73. In the inscriptions found on the Mentuhotep-Nebhepetre tablets (see note 71 above) the name is written with the nome sign. See also the Egyptian alabaster tablet of Montuhotep-Seankhkare from El-Tarif or Dira Abu'n-Naga, now in the Museum of Egyptian Antiquities, Cairo (Dorothea Arnold 1991, p. 17, fig. 20; Postel 2004, p. 363, no. 1387), the inscription on which is repeated almost identically on a carnelian cylinder seal without provenance that is now at Johns Hopkins University (inv. 2086D; Goedicke 1989, pp. 119-20).

74. On the curious and hitherto unexplained variations in how the different forms of the king's name are shown and the distribution of the tablets, see Dieter Arnold 1979, p. 56.

75. The Horus name (Whm-mswt) is the later form encountered with the monarch's titulary (see von Beckerath 1999, pp. 82ff., and Postel 2004, pp. 284-86, 377[10]), but since nothing is known about the date the king changed his titulary, any historical conclusion regarding when the Montu building was erected must remain moot.

\section{REFERENCES}

Abd el-Raziq, Mahmud

1999 "New Inscriptions at el ein El-Sukhna." Memnonia

(Association pour la Sauvegard du Ramesseum, Paris) 10, pp. 125-31.

Abd el-Raziq, Mahmud, Georges Castel, Pierre Tallet, and Victor Ghica

2002 Les inscriptions d'Ayn Soukhna. Mémoires publiés par les membres de l'Institut Français d'Archéologie Orientale du Caire 122. Cairo.

Aegyptische Inschriften

1913 Aegyptische Inschriften aus den königlichen Museen zu Berlin. Vol. 1, Inschriften von der ältesten Zeit bis zum Ende der Hyksoszeit. Berlin.

Allam, Schafik

1963 Beiträge zum Hathorkult (bis zum Ende des Mittleren Reiches). Münchner ägyptologische Studien 4. Berlin.

Allen, James P.

2003 "The High Officials of the Early Middle Kingdom." In The Theban Necropolis: Past, Present and Future, edited by Nigel Strudwick and John H. Taylor, pp. 14-29. London: British Museum.

Arnold, Dieter

1974 Der Tempel des Königs Mentuhotep von Deir el-Bahari. Vol. 1, Architektur und Deutung. Archäologische Veröffentlichungen, Deutsches Archäologisches Institut, Abt. Kairo, Berlin/Mainz 8. Mainz am Rhein.

1979 The Temple of Mentuhotep at Deir el Bahari. Publications of The Metropolitan Museum of Art Egyptian Expedition 21. New York.

1988 The Pyramid of Senwosret I. The South Cemeteries of Lisht, vol. 1. Publications of The Metropolitan Museum of Art Egyptian Expedition 22. New York.

1997 "Royal Cult Complexes of the Old and Middle Kingdoms." In Temples of Ancient Egypt, edited by Byron E. Shafer, pp. 31-85. Ithaca.

n.d. The Pyramid Precinct of Amenemhat I at Lisht: The Architecture. New York: MMA, forthcoming.

\section{Arnold, Dorothea}

1991 "Amenemhat I and the Early Twelfth Dynasty at Thebes." MMJ 26, pp. 5-48.

2008 "Egyptian Art-A Performing Art." In Servant of Mut: Studies in Honor of Richard A. Fazzini, edited by Sue $\mathrm{H}$. D’Auria, pp. 1-18. Probleme der Ägyptologie, vol. 28. Leiden.

Arnold, Dorothea, et al.

1999 Egyptian Art in the Age of the Pyramids. Exh. cat. Galeries Nationales du Grand Palais, Paris; MMA; Royal Ontario Museum, Toronto. New York.

Aston, Barbara G.

1994 Ancient Egyptian Stone Vessels: Materials and Forms. Studien zur Archäologie und Geschichte Altägyptens 5. Heidelberg.

Aufrère, Sydney

1982 "Contribution à l'étude de la morphologie du protocole 'classique.'" Bulletin de I'Institut Français d'Archéologie Orientale (Cairo) 82, pp. 19-73.

Barta, Winfried

1970 Das Selbstzeugnis eines altägyptischen Künstlers (Stele Louvre C 14). Münchner ägyptologische Studien 22. Berlin. von Beckerath, Jürgen

1965 "Zur Begründung der 12. Dynastie durch Ammenemes I." 
Zeitschrift für ägyptische Sprache und Altertumskunde 92, pp. 4-10.

1982 "Mentuhotep IV" and "Mentuhotep V-VI." In Lexikon der Ägyptologie, vol. 4, pp. 69, 70. Wiesbaden.

1997 Chronologie des pharaonischen Ägypten. Die Zeitbestimmung der ägyptischen Geschichte von der Vorzeit bis 332 v. Chr. Münchner ägyptologische Studien 46. Mainz am Rhein.

1999 Handbuch der ägyptischen Königsnamen. 2nd ed. Münchner ägyptologische Studien 49. Mainz am Rhein

Berman, Lawrence Michael

1985 "Amenemhet I. " Ph.D. diss., Yale University, New Haven von Bissing, Wilhelm

1932 "Grundsteinbeigaben Sesostris' I aus dem Tempel von Dendere?" Zeitschrift für ägyptische Sprache und Altertumskunde 68, pp. 68-69.

Bisson de la Roque, Fernand

1931 Rapport sur les fouilles de Médamoud (1930). Fouilles de I'Institut Français d'Archéologie Orientale du Caire 8. Cairo.

1937 Tôd (1934 à 1936). Fouilles de I'Institut Français d'Archéologie Orientale du Caire 17. Cairo.

Bisson de la Roque, Fernand, J. J. Clère, and Étienne Drioton

1928 Rapport sur les fouilles de Médamoud (1927). Fouilles de I'Institut Français d'Archéologie Orientale du Caire 5. Cairo.

Breasted, James Henry, ed. and trans.

1906 Ancient Records of Egypt: Historical Documents from the Earliest Times to the Persian Conquest. Vol. 1, The First to the Seventeenth Dynasties. Chicago.

Callender, Gae

2000 "The Middle Kingdom Renaissance (c. 2055-1650 BC)." In The Oxford History of Ancient Egypt, edited by lan Shaw, pp. 148-83. Oxford and New York.

Chevrier, Henri

1938 "Rapport sur les traveaux de Karnak (1937-1938)." Annales du Service des Antiquités de l'Égypte (Cairo) 38, pp. 567-608.

Clère, J. J., and J. Vandier, trans.

1948 Textes de la première période intermédiare et de la Xlème dynastie. Fasc. 1. Bibliotheca aegyptiaca 10. Brussels.

Couyat, J., and P. Montet

1912 Les inscriptions hiéroglyphiques et hiératiques du Ouâdi Hammamât. Mémoires publiés par les membres de I'Institut Français d'Archéologie Orientale du Caire 34. Cairo.

Daressy, Georges

1904 "Inscriptions hiéroglyphiques du Musée d'Alexandrie." Annales du Service des Antiquités de l'Égypte (Cairo) 5, pp. 113-28.

Donadoni-Roveri, Anna Maria, Elvira D'Amicone, and Enrichetta Leospo

1994 Gebelein: Il villaggio e la necropoli. Turin.

Fakhry, Ahmed

1952 The Inscriptions of the Amethyst Quarries at Wâdi el Hudi. Cairo.

Fischer, Henry G

1968 Dendera in the Third Millennium B.C. down to the Theban Domination of Upper Egypt. Locust Valley, N.Y.

\section{Gabolde, Luc}

2009 "Un assemblage au nom d'Amenemhat ler dans les magasins du temple de Louxor." In Causing His Name to Live: Studies in Egyptian Epigraphy and History in Memory of William J. Murnane, edited by Peter J. Brand and Louise Cooper, pp. 103-8. Leiden.

Gestermann, Louise

1987 Kontinuität und Wandel in Politik und Verwaltung des frühen Mittleren Reiches in Ägypten. Göttinger Orientforschungen, IV. Reihe, vol. 18. Wiesbaden.

Goedicke, Hans

1989 "A Royal Seal of S'ankh-kare'." Varia Aegyptiaca 5, pp. 119-20.

Gomaà, Farouk

1980 Ägypten während der Ersten Zwischenzeit. Beihefte zum Tübinger Atlas des Vorderen Orients, Reihe B (Geisteswissenschaften), no. 27. Wiesbaden.

1987 Die Besiedlung Ägyptens während des Mittleren Reiches. Vol. 2, Unterägypten und die angrenzenden Gebiete. Beihefte zum Tübinger Atlas des Vorderen Orients, Reihe B (Geisteswissenschaften), no. 66, part 2. Wiesbaden.

Goyon, Geoges

1957 Nouvelles inscriptions rupestres du Wadi Hammamat. Paris.

Gundlach, Rolf

1980 "Mentuhotep IV. und Min. Analyse der Inschriften M 110, M 191 und M 192a aus dem Wâdi Hammâmât'." Studien zur altägyptischen Kultur (Hamburg) 8, pp. 89-114.

1999 "Die Neubegründung des Königtums in der 11. Dynastie." In Das frühe ägyptische Königtum: Akten des 2. Symposiums zur ägyptischen Königsideologie in Wien 24.-26.9.1997, edited by Rolf Gundlach and Wilfried Seipel, pp. 21-41. Ägypten und Altes Testament 36, no. 2. Wiesbaden.

Habachi, Labib

1958 "God's Fathers and the Role They Played in the History of the First Intermediate Period." Annales du Service des Antiquités de l'Égypte (Cairo) 55, pp. 167-90.

1963 "King Nebhepetre Menthuhotep: His Monuments, Place in History, Deification and Unusual Representations in the Form of Gods." Mitteilungen des Deutschen Archäologischen Instituts, Abteilung Cairo, 19, pp. 16-52.

Hayes, William C.

1953 The Scepter of Egypt: A Background for the Study of the Egyptian Antiquities in The Metropolitan Museum of Art. Vol. 1, From the Earliest Times to the End of the Middle Kingdom. New York.

1964 The Middle Kingdom in Egypt: Internal History from the Rise of the Heracleopolitans to the Death of Ammenemes III. Rev. ed. Cambridge Ancient History, fasc. 3, vol. 1, chap. 20. Cambridge.

Helck, Wolfgang

1956 Untersuchungen zu Manetho und den ägyptischen Königslisten. Untersuchungen zur Geschichte und Altertumskunde Ägyptens 18. Berlin.

1981 Geschichte des alten Ägypten. Rev. ed. Handbuch der Orientalistik, 1. Abt., Der Nahe und der Mittlere Osten, vol. 1, Ägyptologie, no. 3. Leiden.

Hirsch, Eileen

1994 "Die Kultpolitik Amenemhets I. im Thebanischen Gau." In Ägyptische Tempel: Struktur, Funktion und Programm. Akten der Ägyptologischen Tempeltagungen Gosen 1990 und in Mainz 1992, edited by Rolf Gundlach and Matthias 
Rochholz, pp. 137-42. Hildesheimer ägyptologische Beiträge 37. Hildesheim.

2004 Kultpolitik und Tempelbauprogramme der 12. Dynastie: Untersuchungen zu den Göttertempeln im Alten Ägypten. Achet: Schriften zur Ägyptologie, A3. Berlin.

Hornung, Erik, and Elisabeth Staehelin

2006 Neue Studien zum Sedfest. Aegyptiaca Helvetica, 20. Basel.

James, T. G. H.

1974 Corpus of Hieroglyphic Inscriptions in the Brooklyn Museum. Vol. 1, From Dynasty I to the End of Dynasty XVIII. Brooklyn.

Jánosi, Peter

n.d. The Pyramid Precinct of Amenemhat I at Lisht: The Reliefs. New York: MMA, forthcoming.

Kaiser, Werner, Günter Dreyer, Günter Grimm, Gerhard Haeny, Horst Jaritz, and Christa Müller

1975 "Stadt und Tempel von Elephantine. Fünfter Grabungsbericht." Mitteilungen des Deutschen Archäologischen Instituts, Abteilung Cairo, 31, 39-84.

El-Khouly, Aly

1978 "An Offering-Table of Sesostris I from El-Lisht." Journal of Egyptian Archaeology 64, p. 44, pl. 9.

Mace, A. C.

1921 "Egyptian Expedition for MCMXX-MCMXXI: I. Excavations at Lisht." MMAB 16, no. 11, part 2, pp. 5-19.

Marochetti, E. F.

2005 "The Temple of Nebhepetre Montuhotep at Gebelein. Preliminary Report." In Des Néferkarê aux Montouhotep: Travaux archéologiques en cours sur la fin de la Vle dynastie et la Première Période Intermédiaire. Actes du Colloque CNRS-Université Lumière-Lyon 2, tenu le 5-7 juillet 2001, edited by Laure Pantalacci and Catherine Berger-El-Naggar, pp. 145-63. Travaux de la Maison de l'Orient et de la Méditerranée, no. 40. Lyons.

Maspero, Gaston

1901 "Notes sur la rapport de M. Legrain." Annales du Service des Antiquités de l'Égypte (Cairo) 2, pp. 281-84.

1902 "Note sur les objets recueillis sous la pyramide d'Ounas." Annales du Service des Antiquités de l'Égypte (Cairo) 3, pp. 185-90.

Mond, Robert

1940 Temples of Armant: A Preliminary Survey. 2 vols. London. Morenz, L.

2009 "Vom archaischen Höhlenheiligtum zur Konzeption des Sakralbezirkes als zweites Dendera unter Mentu-hotep (II.)." In 7. Ägyptologische Tempeltagung: Structuring Religion, Leuven 28. September-1. Oktober 2005, edited by René Preys, pp. 191-210. Königtum, Staat und Gesellschaft früher Hochkulturen 3, 2. Wiesbaden.

Müller, Maya

2005 "Die Königsplastik des Mittleren Reiches und ihre Schöpfer: Reden über Statuen-Wenn Statuen reden." In Imago Aegypti: Internationales Magazin für ägyptologische und koptologische Kunstforschung, Bildtheorie und Kulturwissenschaften 1 (pub. 2006), pp. 27-78.

Murnane, William J.

1977 Ancient Egyptian Coregencies. Studies in Ancient

Naville, Édouard Oriental Civilization, no. 40. Chicago.

1907 The XIth Dynasty Temple at Deir el-Bahari. Part 1. Egypt Exploration Society, 28th Memoir. London.
O'Connor, David

1999 "The Dendereh Chapel of Nebhepetre Montuhotep: A New Perspective." In Studies on Ancient Egypt in Honour of H. S. Smith, edited by Anthony Leahy and John Tait, pp. 215-20. Egypt Exploration Society, Occasional Publication 13. London.

Petrie, W. M. Flinders

1903 Abydos. Vol. 2. London.

Porter, Bertha, and Rosalind L. B. Moss

1937 Topographical Bibliography of Ancient Egyptian Hieroglyphic Texts, Reliefs and Paintings. Vol. 5, Upper Egypt: Sites ... . Oxford.

Posener, Georges

1956 Littérature et politique dans l'Égypte de la XIle dynastie. Paris.

Posener-Kriéger, Paule

1989 "Travaux de I'IFAO au cours de l'année 1988-1989." Bulletin de I'Institut Français d'Archéologie Orientale (Cairo) 89, pp. 291-341.

Postel, Lilian

2004 Protocole des souverains égyptiens et dogme monarchique au début du Moyen Empire: Des premiers Antef au début du règne d'Amenemhat ler. Monographies Reine Élisabeth, Brussels 10. Brussels.

Priese, Karl-Heinz, ed.

1991 Ägyptisches Museum. Museumsinsel Berlin. Mainz am Rhein and Berlin.

Pudleiner, Reszö

2001 "Hathor on the Thoth Hill." Mitteilungen des Deutschen Archäologischen Instituts, Abteilung Cairo 57, pp. 239-45.

Radwan, Ali

1983 Die Kupfer- und Bronzegefäße Ägyptens: Von den Anfängen bis zum Beginn der Spätzeit. Prähistorische Bronzefunde Abt. II, vol. 2. Munich.

2006 "Die Göttin Hathor und das göttliche Königtum Altägyptens: Zwei Reliefs aus Deir el-Bahari." In Timelines: Studies in Honour of Manfred Bietak, vol. 1, pp. 27585. Orientalia Lovaniensia Analecta 149, no. 1. Leuven.

Redford, Donald B.

1986 Pharaonic King-Lists, Annals and Day-Books: A Contribution to the Study of the Egyptian Sense of History. SSEA Publication 4. Mississauga, Ontario.

Roth, Silke

2001 Die Königsmütter des Alten Ägypten von der Frühzeit bis zum Ende der 12. Dynastie. Ägypten und Altes Testament 46. Wiesbaden.

Ryholt, Kim S. B.

1997 The Political Situation in Egypt during the Second Intermediate Period, c. 1800-1550 B.C. Carsten Niebuhr Institute Publications 20. Copenhagen.

2006 "The Royal Canon of Turin." In Ancient Egyptian Chronology, edited by E. Hornung, R. Krauss, and D. A. Warburton, pp. 26-32. Handbook of Oriental Studies, Section I, The Near and Middle East, vol. 83. Leiden.

Schäfer, Heinrich, and Walter Andrae

1925 Die Kunst des Alten Orients. Berlin.

Schenkel, Wolfgang

1965 Memphis, Herakleopolis, Theben: Die epigraphischen Zeugnisse der 7.-11. Dynastie Ägyptens. Ägyptologische Abhandlungen 12. Wiesbaden.

Schneider, Thomas

2002 Lexikon der Pharaonen. Düsseldorf. 
Seidlmayer, Stephan J.

2006 "First Intermediate Period." In Ancient Egyptian Chronology, edited by Erik Hornung, Rolf Krauss, and David A. Warburton, pp. 159-67. Handbook of Oriental Studies, Section 1, The Near and Middle East, vol. 83. Leiden.

Sethe, Kurt

$1914 \quad$ Urkunden der 18. Dynastie. Leipzig.

Seyfried, Karl-Joachim

1981 Beiträge zu den Expeditionen des Mittleren Reiches in die Ost-Wüste. Hildesheimer ägyptologische Beiträge

15. Hildesheim.

Simpson, William Kelly

1954 "The Pyramid of Amen-em-het I at Lisht." Ph.D. diss., Yale University, New Haven.

1959 "Historical and Lexical Notes on the New Series of Hammamat Inscriptions." Journal of Near Eastern Studies 18, pp. 20-37.

1963 "Studies in the Twelfth Egyptian Dynasty: I-II." Journal of the American Research Center in Egypt (Boston) 2, pp. 53-63.

Spalinger, Anthony J.

1984 "Sobekhotep I-VIII." In Lexikon der Ägyptologie, vol. 5, pp. 1036-49. Wiesbaden.

Staatliche Sammlung Ägyptischer Kunst

1976 Staatliche Sammlung Ägyptischer Kunst: München, Residenz Hofgartenstrasse. 2nd ed. Munich.

Stock, Hanns

1949 Die erste Zwischenzeit Ägyptens: Untergang der Pyramidenzeit, Zwischenreiche von Abydos und Herakleopolis, Aufstieg Thebens. Analecta Orientalia 31; Studia Aegyptiaca II. Rome.

Troy, Lana

1986 Patterns of Queenship in Ancient Egyptian Myth and History. Acta Universitatis Upsaliensis, Boreas 14. Uppsala.
Ullmann, Martina

2007 "Thebes: Origins of a Ritual Landscape." In Sacred Space and Sacred Function in Ancient Thebes, edited by Peter F. Dorman and Betsy M. Bryan, pp. 3-25. Studies in Ancient Oriental Civilization, no. 61. Chicago.

Vandersleyen, Claude

1995 L'Égypte et la vallée du Nil. Vol. 2, De la fin de l'Ancien Empire à la fin du Nouvel Empire. Paris.

Vandier, Jacques

1936 "Un nouvel Antef de la Xle dynastie." Bulletin de I'Institut Français d'Archéologie Orientale (Cairo) 36, pp. 101-16.

Weinstein, James Morris

1973 "Foundation Deposits in Ancient Egypt." Ph.D. diss., University of Pennsylvania, Philadelphia

Werner, Edward K.

1985 "The God Montu: From the Earliest Attestations to the End of the New Kingdom. " Ph.D. diss., Yale University, New Haven.

2001 "Montuhotep I, Nebhepetre." In The Oxford Encyclopedia of Ancient Egypt, edited by Donald B. Redford, vol. 2, pp. 436-38. Oxford.

Wildung, Dietrich

1969 Die Rolle, ägyptischer Könige im Bewußtsein ihrer Nachwelt. Vol. 1, Posthume Quellen über die Könige der ersten vier Dynastien. Münchner ägyptologische Studien 17. Berlin.

Winlock, Herbert E.

1941 "Neb-hepet-Re Mentu-Hotpe of the Eleventh Dynasty." Journal of Egyptian Archaeology 26 (February), pp. 116-19.

1943 "The Eleventh Egyptian Dynasty." Journal of Near Eastern Studies 2, pp. 249-83.

1947 The Rise and Fall of the Middle Kingdom in Thebes. New York. 